\title{
Asfixie perinatală asociată cu sepsis neonatal precoce cu Listeria monocytogenes- prezentare de caz
}

\author{
Andreea Calomfirescu-Avramescu ${ }^{1}$, Mihaela Demetrian ${ }^{1}$, Andreea Vidru', \\ Georgeta Grecu', Vlad Dima', Ioan Gherghina ${ }^{2}$ \\ ${ }^{1}$ Spitalul Clinic „Filantropia“, Bucureşti, România \\ ${ }^{2}$ Institutul Național pentru Sănătatea Mamei şi Copilului “Alessandrescu- Rusescu” (INSMC)
}

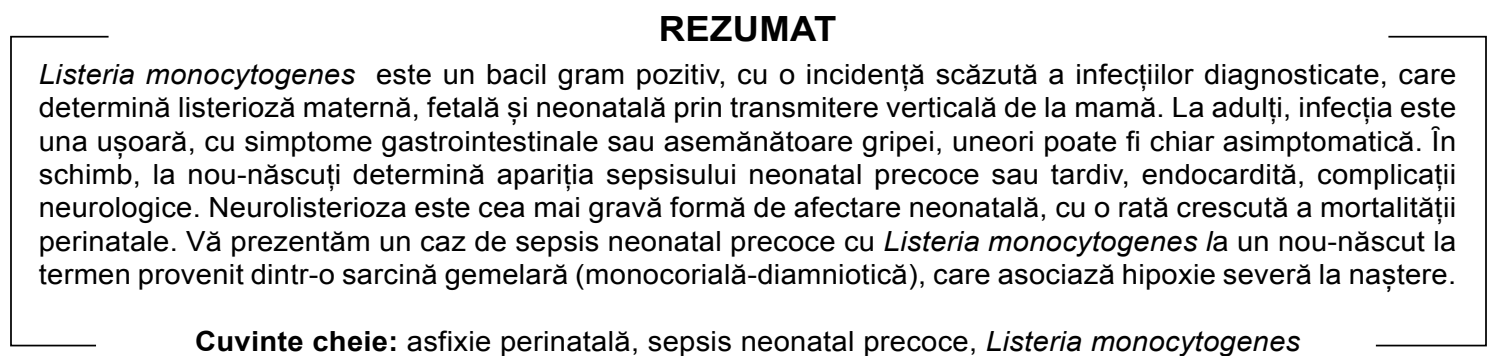

\section{INTRODUCERE}

Listeria monocytogenes este un bacil gram pozitiv care se transmite prin consumul de alimente (lapte, brânză, carne) contaminate, cu o incidență scăzută a infecțiilor diagnosticate, dar se preconizează o creștere în ultimii ani, mai ales în cazul femeilor de origine hispanică (1). Ea poate determina listerioză maternă, fetală și neonatală prin transmitere verticală de la mamă (transplacentar, naștere vaginală, hematogen). Infecțiile grave cu Listeria se împart în 3 forme: sepsis, neurolisterioză și infecțiile materno-fetale (2).

Infecția în timpul sarcinii determină avort spontan, naștere prematură, moartea fătului in utero sau corioamniotită și adesea este subdiagnosticată (3). La adulţi, infecția este una uşoară, cu simptome gastrointestinale sau asemănătoare gripei, uneori poate fi chiar asimptomatică. În schimb, la nounăscuți determină apariţia sepsisului neonatal precoce sau tardiv, endocardită, complicații neurologice $(4,5)$.
Diagnosticul neonatal al infecției cu Listeria este unul provocator din cauza specificității scăzute a hemoculturilor sau a culturilor din lichid cefalorahidian pentru Listeria. În funcție de stadiul de dezvoltare a bacteriei, ele pot apărea sub formă de coci și pot fi greu detectabile în colorația Gram, necesitând realizarea de culturi seriate. Fiind o infecție atât de rară, rata testărilor pentru Listeria este una foarte mică (6).

Manifestările clinice raportate în cazurile neonatale au fost de sepsis neonatal precoce sau tardiv, pneumonie congenitală, detresă respiratorie și febră. Alte simptome includ semne neurologice, erupții cutanate și icter. Neurolisterioza este cea mai gravă formă de afectare neonatală, cu o rată crescută a mortalității perinatale. Afectarea respiratorie la naştere determină apariția asfixiei perinatale şi a encefalopatiei hipoxic-ischemice de gradul II sau III (7).

În 2017, s-a realizat studiul MONALISA, în care sunt prezentați factorii de risc și prognosticul 
infecțiilor cu Listeria monocytogenes. În studiile efectuate în ultimii ani, prognosticul listeriozei neonatale nu s-a îmbunătățit, dar, cu cât suspiciunea diagnosticului este mai mare, cu atât investigațiile paraclinice trebuie efectuate cât mai rapid, precum și adaptarea corectă a tratamentului pentru reducerea bacteriemiei (8).

\section{PREZENTARE DE CAZ}

Vă prezentăm cazul unui nou-născut transferat în clinica noastră la 5 ore de viaţă pentru tratament cu hipotermie controlată. Provenit din sarcină gemelară monocorială-diamniotică, parțial investigată, infecție de tract urinar în trimestrul III de sarcină cu Listeria monocytogenes. Mama, de 38 de ani, trigestă, primipară fără antecedente personale patologice semnificative, IMC normal, nefumătoare, fără expunere la mediu toxic, tensiune arterială normală, glicemii normale. Sarcina nu a fost urmărită în clinica noastră, dar investigațiile paraclinice efectuate au arătat TORCH negativ, analizele uzuale în limite normale și o urocultură pozitivă in trimestrul trei de sarcină cu Listeria. Ecografiile de morfologie fetală au fost în limite normale pentru vârsta de gestație.

Sarcina a fost cu evoluție normală, fără complicații. Travaliul s-a declanşat spontan la 37 de săptămâni de gestație, cu ruperea membranelor și contracții uterine dureroase. S-a prezentat într-o maternitate de grad doi, unde s-a decis terminarea sarcinii prin operație cezariană și s-au extras doi feți vii: geamăna I, de sex feminin, $2.300 \mathrm{~g}$ (percentila $10-25 \%$ ), SA $2 / 4 / 6 / 7$, geamăna II, tot de sex feminin, $2.200 \mathrm{~g}$ (percentila 10-25\%), SA 9/9.

Lichidul amniotic a fost verde, iar examenul morfopatologic al placentei nu a fost disponibil, lohiocultura recoltată la câteva zile după naștere a fost pozitivă pentru Listeria monocytogenes. Mama a urmat antibioterapie, cu evoluție favorabilă.

La naștere, nou-născutul I a necesitat manevre complexe de reanimare (ventilat cu presiune intermitent pozitivă pe balon şi sondă endotraheală, adrenalină iv). A necesitat echilibrare volemică şi metabolică, terapie cu vasopresoare cu Dopamină iv, antibioterapie cu Cefuroxim și Gentamicină. În primele ore de viață, a prezentat convulsii tonicoclonice generalizate, pentru care i s-au administrat Fenobarbital doză de încărcare i.m. și Midazolam în perfuzie continuă. În schimb, nou-născutul II nu a necesitat manevre de resuscitare și a prezentat o adaptare favorabilă.

$\mathrm{Au}$ fost transferați în Spitalul „Filantropia“ pentru iniţierea tratamentului cu hipotermie controlată la geamăna I. Au fost internați în secția de terapie intensivă neonatală. Geamăna I a prezentat stare generală gravă, temperatură intrarectală 36,2 grade Celsius, acrocianoză, intubată și ventilată mecanic, murmur vezicular prezent bilateral fără raluri, cord ritmic fără sufluri, $A V=160 \mathrm{bpm}, \mathrm{TAm}=50 \mathrm{mmHg}$, hipotonă, hiporeactivă (sedată), fără convulsii la momentul transferului. S-a iniţiat imediat hipotermia controlată cu temperatură intrarectală 33,5 grade Celsius, ventilată mecanic în sistem de înaltă frecvență oscilatorie şi volum garantat, ulterior ventilaţie convențională și ventilație mecanică noninvazivă pentru 11 zile. Pacienta a necesitat transfuzie de plasmă izogrup, izoRh, antibioterapie iv cu Meronem și Vancomicină și sedative. Pentru convulsii. s-a administrat perfuzie continuă cu Midazolam, ulterior fenobarbital p.o.

Investigațiile paraclinice au îndeplinit criteriile pentru hipotermie controlată $(\mathrm{pH} 6,89, \mathrm{pCO} 275$ mmHG, BE -19), au asociat leucocitoză cu neutrofilie și probe inflamatorii intens pozitive, fără anemie, fără trombocitopenie, probe de coagulare în limite normale. Culturile periferice recoltate la naştere nu au izolat germeni patogeni, în schimb hemocultura a fost pozitivă pentru Listeria monocytogenes. Examenul neurologic la internare a încadrat encefalopatia hipoxic ischemică în stadiul Sarnat II, ecografia transfontanelară a fost de aspect normal. S-a realizat înregistrarea aEEG pe parcursul hipotermiei controlate și în primele ore a fost cu microvoltaj, fără a identifica evenimente convulsive, ulterior normalizat.

După 72 de ore de hipotermie controlată, s-a început reîncălzirea cu 0,5 grade Celsius la 2 ore fără a asocia complicații, stabil hemodinamic, fără convulsii. Evoluția nou-născutului a fost favorabilă, cu ameliorarea sindromului funcțional respirator ( a permis detubarea la 8 zile de viaţă, dar s-a menținut oxigenodependent 11 zile), s-a menținut hipotonia axială, fără a repeta evenimente convulsive.

Geamăna II a prezentat încă de la internarea în secția de terapie intensivă neonatală stare generală satisfăcătoare, tegumente rozate cu acrocianoză, echilibrat cardio-respirator, AV 140-50 bpm, cord 
ritmic fără sufluri, TAm 52 mm Hg, murmur vezicular prezent bilateral fără raluri, $\mathrm{SpO} 2>96 \%$ în aer atmosferic, abdomen suplu, ficat, splină în limite normale, tonus și reactivitate bune. Investigațiile paraclinice au arătat leucocitoză cu neutrofilie, fără anemie, fără trombocitopenie și hemocultura pozitivă pentru Listeria monocytogenes. Ecografia transfontanelară de aspect normal și examen neurologic fără modificări patologice. S-a iniţiat antibioterapie cu Meronem și Vancomicină. Evoluția a fost favorabilă cu stare generală bună, echilibrat cardio-respirator, toleranță digestivă bună, curbă ponderală ascendentă, tonus și reactivitate în limite normale.

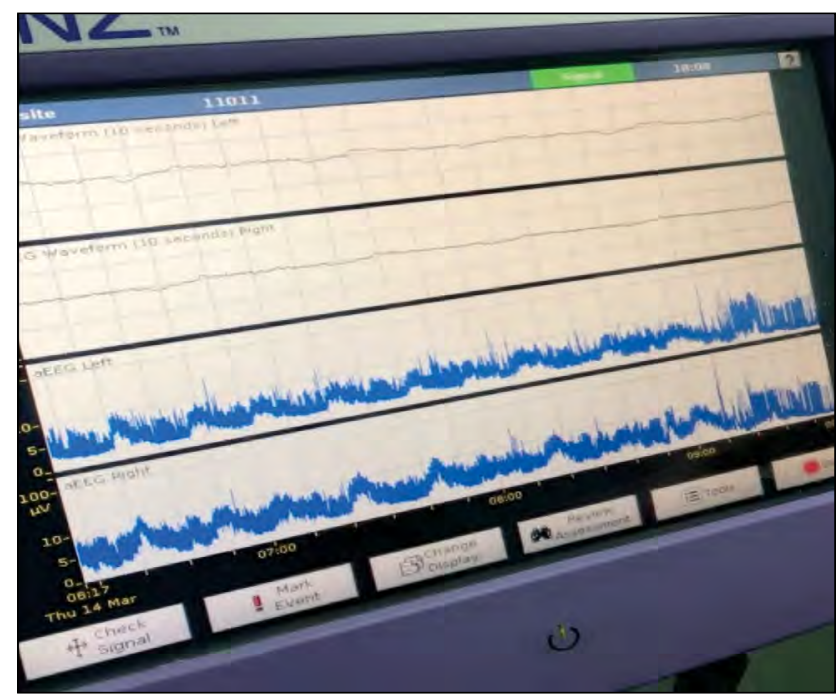

FIGURA 1. Înregistrare aEEG - aspect de microvoltaj fără elemente convulsive

La 13 zile de viață, au fost transferați în compartimentul prematuri, unde evoluția a fost favorabilă pentru ambii gemeni. S-au externat la 19 zile de viață, cu stare generală bună, doar geamăna I își menține hipotonia axială, fără elemente convulsive.

\section{DISCUȚII}

Infecția cu Listeria este una rară și cel mai frecvent nediagnosticată, atât la mamă, cât și la nounăscuți (9). În 30\% dintre cazuri, infecția este asimptomatică (10). În acest caz, deși mama a fost asimptomatică, Listeria a fost izolată în urocultura realizată de rutină din trimestrul trei de sarcină și a urmat cură completă de antibioterapie conform antibiogramei. În ciuda tratamentului antibiotic realizat, infecția a fost transmisă către feți, cu afectarea preponderent a geamănului I. Lohiocultura mamei fiind pozitivă pentru Listeria, nu s-a mai realizat hemocultură, deoarece avea o sensibilitate scăzută (11).

Sarcina fiind monocorială-diamniotică, a asociat infecție materno-fetală a ambilor feți. În cazul de față, deși Listeria a fost izolată în ambele hemoculturi ale gemenilor, doar unul dintre ei a dezoltat hipoxie severă la naștere, celălalt fiind fără manifestări clinice (12). În lipsa tratamentului antibiotic corespunzător, nu putem afirma dacă și geamănul II ar fi dezvoltat o formă clinică a infecție cu Listeria.

Listerioza neonatală care asociază complicații neurologice prezintă o rată mare a mortalității perinatale (5). În cazul prezentat, tratamentul cu hipotermie controlată realizat în primele 6 ore de viață și asocierea antibioterapiei au determinat o evoluție favorabilă a nou-născuților, fără sechele neurologice.

Tratamentul encefalopatiei hipoxic-ischemice cu hipotermie controlată a întregului corp iniţiat în primele 6 ore de la naștere și continuat timp de 72 de ore, până la reîncălzirea completă, scade rata mortalității și a sechelelor neurologice la nounăscuții la termen (13). Geamănul I a îndeplint criteriile realizării hipotermiei controlate și, astfel, evoluția neurologică ulterioară a fost una favorabilă, fără sechele.

În ultimii ani, studiile s-au concentrat pe identificarea cât mai precoce a infecției cu Listeria și testarea tuturor femeilor din zonele endemice, chiar asimptomatice, pentru a preveni transmiterea la făt (14). Au realizat protocoale pentru identificarea semnelor de alarmă ce ar putea fi prezente în infecția cu Listeria.

Managementul neadecvat, lipsa diagnosticării la timp și tratamentul necorespunzător în timpul sarcinii determină apariția complicațiilor neonatale. La femeile însărcinate, complicațiile sunt minime, cu remiterea simptomatologiei după administrarea tratamentului antibiotic. În schimb, la nou-născuți, complicațiile sunt grave, cu asocierea unui rate crescute a mortalității perinatale (15).

\section{CONCLUZII}

În urma prezentării acestui caz, putem afirma că, deși sarcina a fost una gemelară monocorială- 
diamniotică, afectarea a fost doar pe unul dintre feți, respectiv geamăna I. Promptitudinea diagnosticului și a tratamentului a făcut ca geamăna I să nu prezinte complicații neurologice grave cu sechele ulterioare.
Conflict of interest: none declared Financial support: none declared

\title{
$\overline{\text { BIBLIOGRAFIE }}$
}

1. Pohl AM, Pouillot R, van Doren JM. Changing US population demographics: What does this mean for listeriosis incidence and exposure? Foodborne Pathog Dis. 2017;14:524-530.

2. McLauchlin J. Human listeriosis in Britain, 1967-85, a summary of 722 cases. 1. Listeriosis during pregnancy and in the newborn. Epidemiol Infect. 1990;104:181-89.

3. Janakiraman V. Listeriosis in pregnancy: Diagnosis, treatment, and prevention. Rev Obstet Gynecol. 2008;1:179-185.

4. Sailer S, Badia PRB, Vetter-Laracy SIC, Benítez-Segura I, de Gopegui Bordes ER. Neonatal Listeriosis and The Importance of Body Surface Cultures. Klin Padiatr. 2018 Sep;230(5):278-280.

5. Siegman-Igra $Y$ et al. Listeria monocytogenes Infection in Israel and Review of Cases Worldwide. Emerg. Infect. Dis. 2002;8:305-310.

6. Polin R et al. Management of Neonates With Suspected or Proven Early-Onset Bacterial Sepsis. Pediatrics 2012;129:1006-1015.

7. Dramowski A, Lloyd LG, Bekker A, Holgate S, Aucamp M, Reddy K, Finlayson $\mathrm{H}$. Neonatal listeriosis during a countrywide epidemic in South Africa: A tertiary hospital's experience. S Afr Med J. 2018 Oct 2; 108(10):818-827.

8. Charlier C, Perrodeau É, Leclercq A, Cazenave B, Pilmis B, Henry B, Lopes A, Maury MM, Moura A, Goffinet F, Dieye HB, Thouvenot P, Ungeheuer MN, Tourdjman M, Goulet V, de Valk H, Lortholary O, Ravaud P, Lecuit M; MONALISA study group. Clinical features and

prognostic factors of listeriosis: The MONALISA national prospective cohort study. Lancet Infect Dis. 2017 May;17(5):510-519.

9. Orsi RH, den Bakker HC, Wiedmann M. Listeria monocytogenes lineages: Genomics, evolution, ecology, and phenotypic characteristics. Int J Med Microbiol 2011;301(2):79-96.

10. Fouks Y, Amit S, Many A et al. Listeriosis in pregnancy: Underdiagnosis despite over-treatment. J Perinatol. 2018;38:26-30.

11. Madjunkov M, Chaudhry S, Ito S. Listeriosis during pregnancy. Arch Gynecol Obstet. 2017;296:143-152.

12. Coutinho Nunes F, Domingues AP, Vide Tavares M et al. Monochorionic versus dichorionic twins: Are obstetric outcomes always different? Journal of Obstetrics and Gynaecology. 2016;36(5):598-601.

13. Shankaran S, Laptook AR, Ehrenkranz RA, Tyson JE, McDonald SA, Donovan EF, Jobe AH. Whole-Body Hypothermia for Neonates with Hypoxic-Ischemic Encephalopathy. New England Journal of Medicine. 2005; 353(15):1574-1584.

14. National Institute for Communicable Diseases. Situation update on listeriosis outbreak, South Africa. 13 April 2018. http://www.nicd. ac.za/index.php/nicd-listeriosis-situation-report-13-april-2018/ (accessed 18 April 2018).

15. Charlier $C$, Goffinet F, Azria E et al. Inadequate management of pregnancy-associated listeriosis: Lessons from four case reports. Clin Microbiol Infect. 2014;20:246-249

\section{ANNUAL SUBSCRIPTION FEES 2020}

Annual subscription fees for 2020 are now available at:

https://abonamente.medica.ro/

\section{SUBMITTING A MANUSCRIPT}

Authors are strongly encouraged to review the entire "Instructions for authors" document to ensure that the manuscript is properly prepared and formatted, available at:

\author{
https://RJID.com.ro/
}

IMPORTANT:

According to CMR accreditation No. 12001/23.01.2020 after subscribing the Romanian Journal of Infectious Diseases you will receive a Certificate with $10 \mathrm{EMC}$ credits (4 issues per subscription yearly).

The Certificate (the original art-work in ready-to-print form) will be sent, along with the first issue of the Journal to which you subscribed, at the subscriber's e-mail address.

\section{HOW TO RECEIVE THE PRINTED JOURNALS? By ordinary mail:}

- ALL mailing costs will be supported ENTIRELY by the publisher!

Useful: If you are a member of the Romanian National Society of Infectious Diseases or a subscriber, but you haven't received our journal, please call the Publishing House, at 0742155511. 